\title{
Leaf degradation of Salix humboldtiana Willd. (Salicaceae) and invertebrate colonization in a subtropical lake (Brazil)
}

\author{
Degradação foliar de Salix humboldtiana Willd. (Salicaceae) e \\ colonização por invertebrados em um lago subtropical (Brasil)
}

Franko Telöken $^{1}$, Edélti Faria Albertoni ${ }^{2}$ and Cleber Palma-Silva ${ }^{2}$

'Programa de Pós-graduação em Biologia de Ambientes Aquáticos Continentais, Instituto de Ciências Biológicas, Universidade Federal do Rio Grande - FURG, Av. Itália, Km 8, s/nº, Campus Carreiros, CEP 962001-900, Rio Grande, RS, Brazil e-mail: bioteloken@yahoo.com.br

${ }^{2}$ Laboratório de Limnologia, Instituto de Ciências Biológicas, Universidade Federal do Rio Grande - FURG, Av. Itália, Km 8, s/nº, Campus Carreiros, CEP 962001-900, Rio Grande, RS, Brazil e-mail: efalbertoni@gmail.com; dmbcps@furg.br

\begin{abstract}
Aim: To evaluate leaf degradation and invertebrate colonization of Salix humboldtiana Willd. in a subtropical shallow lake on the coastal plain of Rio Grande do Sul, Brazil; Methods: Litter bags containing $6.85 \mathrm{~g}$ of leaves were incubated in the superficial layer of sediment in the littoral region for 1, 4, 7, 14, 32, 47 and 71 days; Results: After 71 days, a loss of $51 \%$ of the initial leaf weight was observed $\left(k=0.0100 \mathrm{~d}^{-1}\right)$. We estimated that it would take 300 days to lose $95 \%$ of the initial weight. A total of 16040 organisms and 35 taxa were identified. Caenidae (25.9\%), Oligochaeta (19\%), Ostracoda (13.8\%), Hydracarina (9.8\%), Tanypodinae (9.7\%) and Coenagrionidae $(7.7 \%)$ were the most highly represented taxa. We observed increases in density, richness and diversity of taxa over time, with a stabilizing trend noted in the taxa diversity. Regarding the functional trophic groups (FTGs), gathering-collectors accounted for $57.6 \%$ of the community, while predators (25\%), scrapers (15.8\%), filtering-collectors $(0.88 \%)$ and shredders $(0.73 \%)$ were also represented. The diversity and evenness of the FTGs had stabilized by day 14; Conclusions: $S$. humboldtiana detritus provides a favorable habitat for a sufficient duration to support a high density and diversity of aquatic invertebrates. The small percentage of shredders indicates the minor influence of the invertebrate community on the rate of detrital degradation. The main contribution of invertebrates to detrital processing comes from the consumption of fine particulate organic matter by gathering-collectors.
\end{abstract}

Keywords: leaf decay coefficients, decomposition, functional trophic groups, sandy coastal plain.

Resumo: Objetivos: Avaliar a degradaçấo foliar de Salix humboldtiana Willd. e a colonizaçáo pela comunidade de invertebrados aquáticos em um lago raso subtropical, planície costeira do Rio Grande do Sul, Brasil; Métodos: Bolsas de decomposição contendo $6,85 \mathrm{~g}$ de folhas foram incubadas na regiāo litorânea, na superfície do sedimento, e retiradas após 1, 4, 7, 14, 32, 47 e 71 dias de decomposição; Resultados: Aos 71 dias foi registrada a degradação de $51 \%$ do peso inicial $\left(k=0,0100 \mathrm{~d}^{-1}\right)$. O tempo estimado para a degradaçáo de $95 \%$ do peso inicial dos detritos foi 300 dias. Foram identificados 16.040 organismos, distribuídos em 35 táxons. Caenidae (25,9\%), Oligochaeta (19\%), Ostracoda (13,8\%), Hydracarina (9,8\%), Tanypodinae (9,7\%) e Coenagrionidae (7,7\%) foram os táxons mais representativos. Foi observado incremento na riqueza, densidade e diversidade dos táxons ao longo do tempo, com tendência à estabilização dos valores de diversidade. Em relação aos grupos tróficos funcionais (GTFs), coletores-catadores representaram $57,6 \%$ da comunidade, enquanto predadores (25\%), raspadores $(15,8 \%)$, coletores-filtradores $(0,88 \%)$ e fragmentadores $(0,73 \%)$ também foram representados. A diversidade e homogeneidade dos GTFs apresentaram estabilização a partir do $14^{\circ}$ dia; Conclusóes: Os detritos de $S$. humboldtiana fornecem um habitat favorável por tempo suficiente para suportar alta densidade e diversidade de invertebrados aquáticos. A baixa abundância de fragmentadores indica pouca influência da comunidade de invertebrados na velocidade de degradaçáo dos detritos. A principal contribuição desta comunidade no processamento dos detritos ocorre por meio do consumo de matéria orgânica particulada fina por coletores-catadores.

Palavras-chave: coeficientes de degradaçẫo foliar, decomposição, grupos tróficos funcionais, planície costeira arenosa. 


\section{Introduction}

The organic detritus of aquatic systems derives from the autochthonous production and input of allochthonous organic matter (Webster and Benfield, 1986). The latter is less important as an energy resource for most lentic systems; however, it can significantly influence the food chains in lakes associated with developed riparian forests (Pieczynska, 1986).

The decomposition of detritus in aquatic environments involves a series of events, e.g., leaching of soluble compounds, colonization and conditioning of detritus by microbial action, fragmentation by physical abrasion and colonization and processing by aquatic invertebrates (Webster and Benfield, 1986; Bianchini Jr, 1999; Pope et al., 1999; Abelho, 2001). This complex process involves both abiotic and biotic factors and is frequently used to assess the functional and structural integrity of ecosystems (Pascoal et al., 2003; Lecerf et al., 2006).

An ecological succession process takes place on the detritus, involving microorganisms, invertebrates and vertebrates (Begon et al., 1996; Gonçalves et al., 2003), until the detritus are completely decomposed. According to Janke and Trivinho-Strixino (2007), the association between aquatic invertebrates and detrital decomposition is not completely clear, but detritus is known to provide food and shelter to these organisms (Dudgeon and Wu, 1999; Graça, 2001). This community can present a great diversity of species, which may result in the redundancy of individual functions (Lawton, 1991; Wallace and Webster, 1996). Species diversity and functional redundancy are crucial to the integrity and stability of ecosystems (Odum and Barrett, 2007). Therefore, freshwater ecology studies of detritivorous invertebrates have traditionally focused on the roles of these organisms in the processing of organic matter. Different taxa have been classified into functional trophic groups (FTGs) as shredders, gathering-collectors, filteringcollectors, predators or scrapers (Begon et al., 1996; Callisto et al., 2001; Cummins et al., 2005; Merritt et al., 2008).

In shallow lakes, the detrital food chain can consume half of the net primary production (Odum and Barrett, 2007). Most studies on decomposition in lentic systems refer to macrophytes (e.g., Cunha and Bianchini Jr, 1998, 1999; Asaeda et al., 2000; Gonçalves et al., 2000, 2003, 2004; Kim and Rejmánková, 2004; Kufel et al., 2004; Shilla et al., 2006). There is little information about the decomposition of allochthonous detritus originating from trees or its colonization by invertebrates in lakes (Webster and Benfield, 1986; Pope et al., 1999; Sampaio et al., 2008).

The pioneer tree species, Salix humboldtiana Willd., grows on the banks of streams, lakes, ponds or in environments with abundant groundwater in South and Central America (Backes and Irgang, 2002; Carvalho, 2003). This species is common and abundant in the study area (Trindade et al., 2009, 2010), and Aceñolaza et al. (2010) showed that $S$. humboldtiana produces a large quantity of leaf litter in the flood plain forest of the Paraná River (Argentina). Studies on the leaf decomposition of S. humboldtiana are scarce, with the exception of Leguizamon et al. (1992), Capello et al. (2004) and Poi de Neiff et al. (2006), which were all performed in the hydrological system of the Paraná River, Argentina.

Considering the abundance of $S$. humboldtiana in the riparian forests of the study region, its significant contribution to the detritus of aquatic environments and the participation of detritivorous invertebrates in the processing of organic matter, this study aimed to analyze the community of aquatic invertebrates colonizing S. humboldtiana leaf detritus in a subtropical lake and to estimate the leaf degradation coefficients $(k)$ in this environment. We hypothesized that (i) allochthonous detritus from S. humboldtiana provides shelter for aquatic invertebrates and that (ii) the invertebrate community influences the rate of detrital degradation.

\section{Material and Methods}

\subsection{Study area}

The aquatic ecosystems of the sandy coastal plain of Rio Grande do Sul (Southern Brazil) mainly comprise wetlands and shallow lakes (Vieira and Rangel, 1988). The climate of this region is characterized as $\mathrm{Cfa}$ (humid subtropical) by the Köppen classification. The average annual temperature varies between $13{ }^{\circ} \mathrm{C}$ (winter) and $24^{\circ} \mathrm{C}$ (summer), and total annual rainfall is between 1200 and $1500 \mathrm{~mm}$ (Klein, 1998).

The study was conducted at Polegar Lake $\left(32^{\circ} 01^{\prime} 40^{\prime \prime} \mathrm{S}\right.$ and $\left.52^{\circ} 05^{\prime} 40^{\prime \prime} \mathrm{W}\right)$, located at the Campus Carreiros of the Federal University of Rio Grande, municipality of Rio Grande, Rio Grande do Sul State, Brazil. The lake area is approximately $1 \mathrm{ha}$, with an average depth of $1.5 \mathrm{~m}$ that varies by rainfall. It is characterized as an oligotrophic lake, with low primary production 
and nutrient concentrations (Albertoni et al., 2007; Furlanetto et al., 2008; Trindade et al., 2008; Marinho et al., 2009). The sediment is sandy and contains low concentrations of nutrients and organic matter (Leonardo Marques Furlanetto, personal communication). During the study period, the mean water temperature was $23.95^{\circ} \mathrm{C}( \pm 1.64)$; the $\mathrm{pH}$ was $7.4( \pm 0.96)$; and the concentrations of dissolved oxygen, chlorophyll- $a$, total nitrogen and total phosphorus were $6.73 \mathrm{mg} \cdot \mathrm{L}^{-1}( \pm 1.28)$, $8.34 \mu \mathrm{g} . \mathrm{L}^{-1}( \pm 8.86), 0.5719 \mathrm{mg} \cdot \mathrm{L}^{-1}( \pm 1.339)$ and $0.0153 \mathrm{mg} . \mathrm{L}^{-1}( \pm 0.008)$, respectively.

\subsection{Methodology}

Between March and May 2009, 21 litter bags containing $6.85 \mathrm{~g}$ of $S$. humboldtiana leaves, collected directly from adult trees and air-dried, were incubated in the littoral region of Polegar Lake. The bags were $20 \times 30 \mathrm{~cm}$ in size, with a mesh size of $0.1 \mathrm{~cm}$ on the side facing the sediment and $1.0 \mathrm{~cm}$ on the side facing the water column (adapted from Bedford, 2004). Three litter bags were collected after $1,4,7,14,32,47$ and 71 days of incubation. In the laboratory, the remaining leaves were washed over a sieve (mesh size $250 \mu \mathrm{m}$ ), and the invertebrates were sorted, fixed in $80 \%$ alcohol and identified using a stereomicroscope (30x magnification) following specific taxonomic keys (Thorp and Covich, 1991; Elmoor-Loureiro, 1997; Buckup and Bond-Buckup, 1999; Merritt et al., 2008; Mugnai et al., 2010). The remaining leaves were dried at $60{ }^{\circ} \mathrm{C}$ for 48 hours to determine the dry weight. Linear regression was performed following Bärlocher (2005) to calibrate the air-dried weight against the oven-dried weight.

The density of invertebrates was expressed as the number of individuals per $100 \mathrm{~g}$ of detritus dry weight (ind.100 g. $\mathrm{DW}^{-1}$ ). The abundance (\%) of each taxa was calculated. The succession of the most representative taxa (abundance $>7.68$ ) was analyzed. Aquatic invertebrate composition and structure were evaluated according to Magurran (2004), using richness (taxa number), diversity (Shannon-Wiener Index) and evenness (Pielou Index).

To determine the pattern of succession of organisms in relation to their use of detrital resources, invertebrates were classified according to their FTGs as shredders, gathering-collectors, filteringcollectors, predators or scrapers (Callisto et al., 2001; Cummins et al., 2005; Merritt et al., 2008). Diversity (Shannon-Wiener Index) and evenness (Pielou Index) were calculated in relation to the
FTGs. This analysis omitted chironomid pupae. Invertebrates were deposited in the Subtropical Limnic Invertebrate Collection (Limnology Laboratory, Biological Science Institute, Federal University of Rio Grande, Brazil).

Using the model proposed by Petersen and Cummins (1974), for each sampling, the percentage of remaining leaves and the leaf decay coefficient $(k)$ were calculated using the equations $\% \mathrm{R}=\left(\mathrm{W}_{\mathrm{t}} / \mathrm{W}_{0}\right)^{*} 100$ and $k=-(1 / \mathrm{t})^{*} \ln \left(\mathrm{W}_{\mathrm{t}} / \mathrm{W}_{0}\right)$, respectively, where $\mathrm{W}_{\mathrm{t}}$ is the dry weight at time $t$ and $W_{0}$ is the initial dry weight. We estimated the number of days needed for the degradation of $95 \%$ of the original leaf material with the equation $\mathrm{t}=-\ln (\% \mathrm{R} / 100) / k$, using the $k$ value estimated for the last sampling period.

All data on leaf degradation and aquatic invertebrates were $\log (x+1)$-transformed. The averages were tested using analysis of variance (ANOVA - one way) followed by the Tukey test, using $\mathrm{p}<0.05$ and 6 degrees of freedom for all tests. A presence-absence matrix was constructed to compare the similarity (Jaccard) of samples and to order all samples during the decomposition process.

\section{Results}

After 24 hours of incubation, leaf mass loss was $30 \%\left(k=0.3520 \mathrm{~d}^{-1} \pm 0.0443\right)$ (Figure 1). The decay velocity then diminished until day 32 . Subsequent variation in this coefficient exhibited a stabilizing trend. After 71 days of incubation, we measured a $51 \%$ loss of the initial dry weight $\left(k=0.0100 \mathrm{~d}^{-1}\right.$ $\pm 0.0002)$. The length of the period that would result in a loss of $95 \%$ of the initial dry weight was estimated at 300 days. The analysis of variance showed significant differences between decay coefficients over time $(F=210.1)$ (Figure 1). The percentage of remaining leaf detritus also showed significant differences over time $(\mathrm{F}=82.50)$.

A total of 16040 organisms and 35 taxa were identified (Table 1). Caenidae (25.9\%), Oligochaeta (19\%), Ostracoda (13.8\%), Hydracarina (9.8\%), Tanypodinae (9.7\%) and Coenagrionidae $(7.7 \%)$ were the most highly represented taxa. These groups represented $85 \%$ of the community. The richness index increased from 15 (24 hours) to 34 at day 71 and exhibited significant differences over time $(F=10.84)$ (Table 1). The density also significantly increased during the decomposition period $(\mathrm{F}=33.36)$, from 2315.03 ind. 100 g.DW ${ }^{-1}( \pm 861.38)$ on the first day to 58881.58 ind. 100 g.DW ${ }^{-1}( \pm 2761.01)$ on 

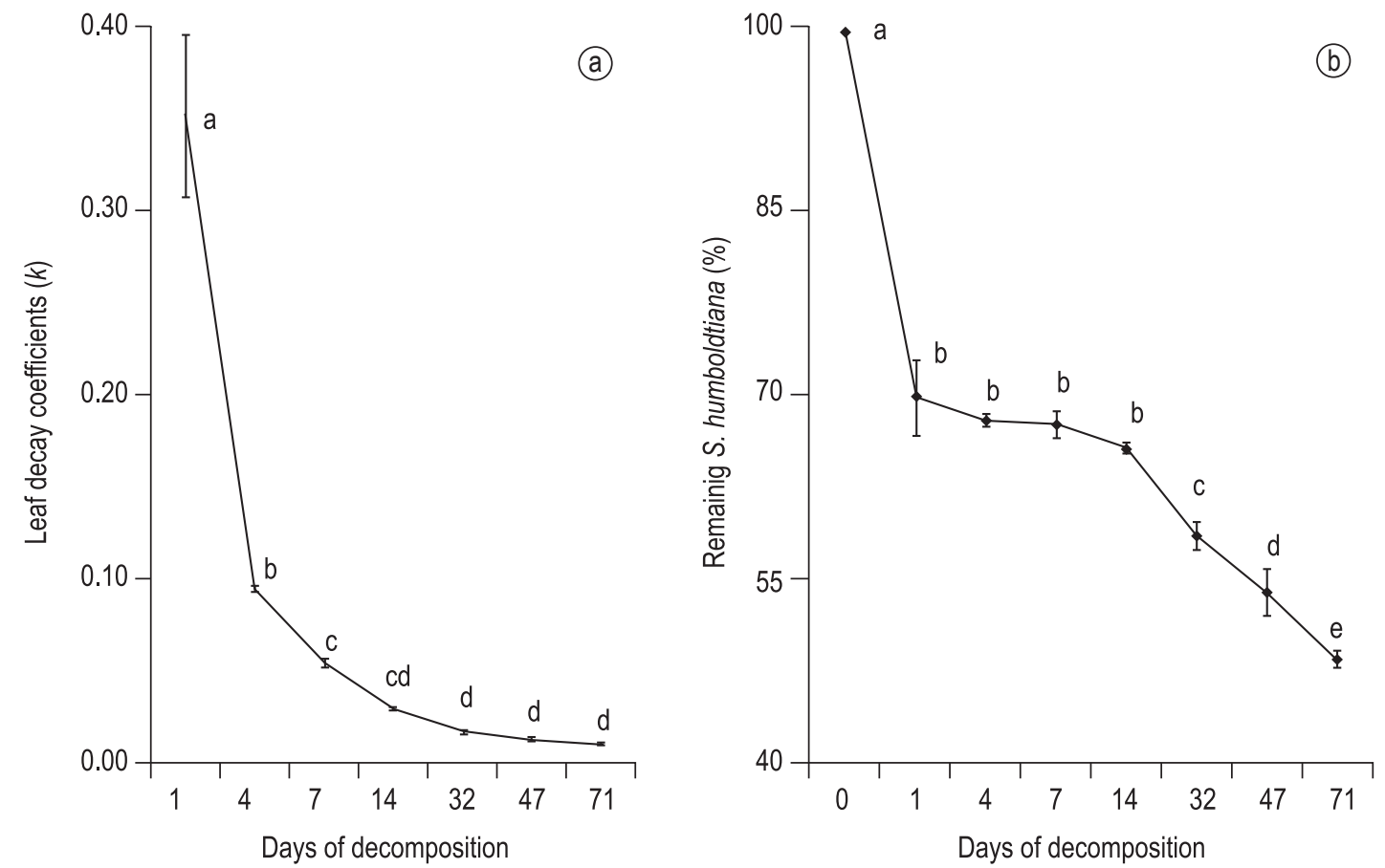

Figure 1. a) Leaf decay coefficients $(k)$; and b) leaf remaining ( $\%$ R) at each sampling day, obtained for Salix humboldtiana in an oligotrophic shallow lake on sand coastal plain of Rio Grande do Sul, Brazil. Different letters represent statistical significant differences $(\mathrm{a}-\mathrm{e})(\mathrm{p}<0.05)$. The bars represent standard deviation.

day 71 (Table 1). This measure showed a linear tendency $\left(\mathrm{R}^{2}=0.91\right)$.

The Shannon diversity index also exhibited an increase over time (Table 1). It presented significant differences $(F=6.58)$ throughout the experiment, ranging from $1.173( \pm 0.404)$ on the first day to $2.051( \pm 0.070)$ on day 71 . Evenness ranged between $0.515( \pm 0.113)$ on the first day and 0.701 $( \pm 0.024)$ on day 14 , with significant differences $(\mathrm{F}=3.394)$. These indexes exhibited stabilizing trends by the end of the experiment.

Community similarity analysis revealed two distinct groups, one corresponding to the initial decomposition phase (from day 1 to day 14) and the second representing the final phase (from day 32 to day 71) (Figure 2). These phases corresponded to the significant differences found in the percentage of remaining leaves and decay coefficients (Figure 1).

The abundance variations of the most highly represented taxa were individually analyzed (Figure 3). Caenidae, Oligochaeta, Hydracarina and Tanypodinae exhibited low abundances during the first day of decomposition. Caenidae increased gradually and represented $39 \%$ of the community by day 32 . Oligochaeta accounted for only $4 \%$ of the community on the first day but increased to $25 \%$ by day 4 . Hydracarina and Tanypodinae each represented $14 \%$ of the total by the last day of the experiment. An analysis of the densities of these groups revealed significant differences (Table 2).

In contrast to those taxa cited above, Ostracoda and Coenagronidae showed inverse patterns of abundance. Ostracoda represented $61 \%$ of the total number of organisms on the first day but decreased to $5 \%$ on day 71 . Coenagrionidae represented $10 \%$ of the total on the first day, increased to $19 \%$ on days $7-14$, and then decreased to less than $2 \%$ at the end of the experiment. Coenagrionidae showed significant differences in density over time (Table 2).

The analysis of FTGs revealed that $57.6 \%$ of the invertebrates were gathering-collectors, $25 \%$ were predators, $15.8 \%$ were scrapers, $0.88 \%$ were filtering-collectors and $0.73 \%$ were shredders. During the first 24 hours of decomposition, gathering-collectors represented $83 \%$ of the total invertebrate abundance (Figure 4). The abundance of this group subsequently decreased but always exceeded $50 \%$ of the total.

The other FTGs generally presented low abundances in the early days of the experiment. Scrapers showed an increase in abundance over time. On day 32, they represented $22.4 \%$ of the community. Predators showed expressive abundance throughout the experiment. This group increased in abundance up to day $14(33.2 \%)$ and then displayed a stabilizing trend. The lowest abundance 


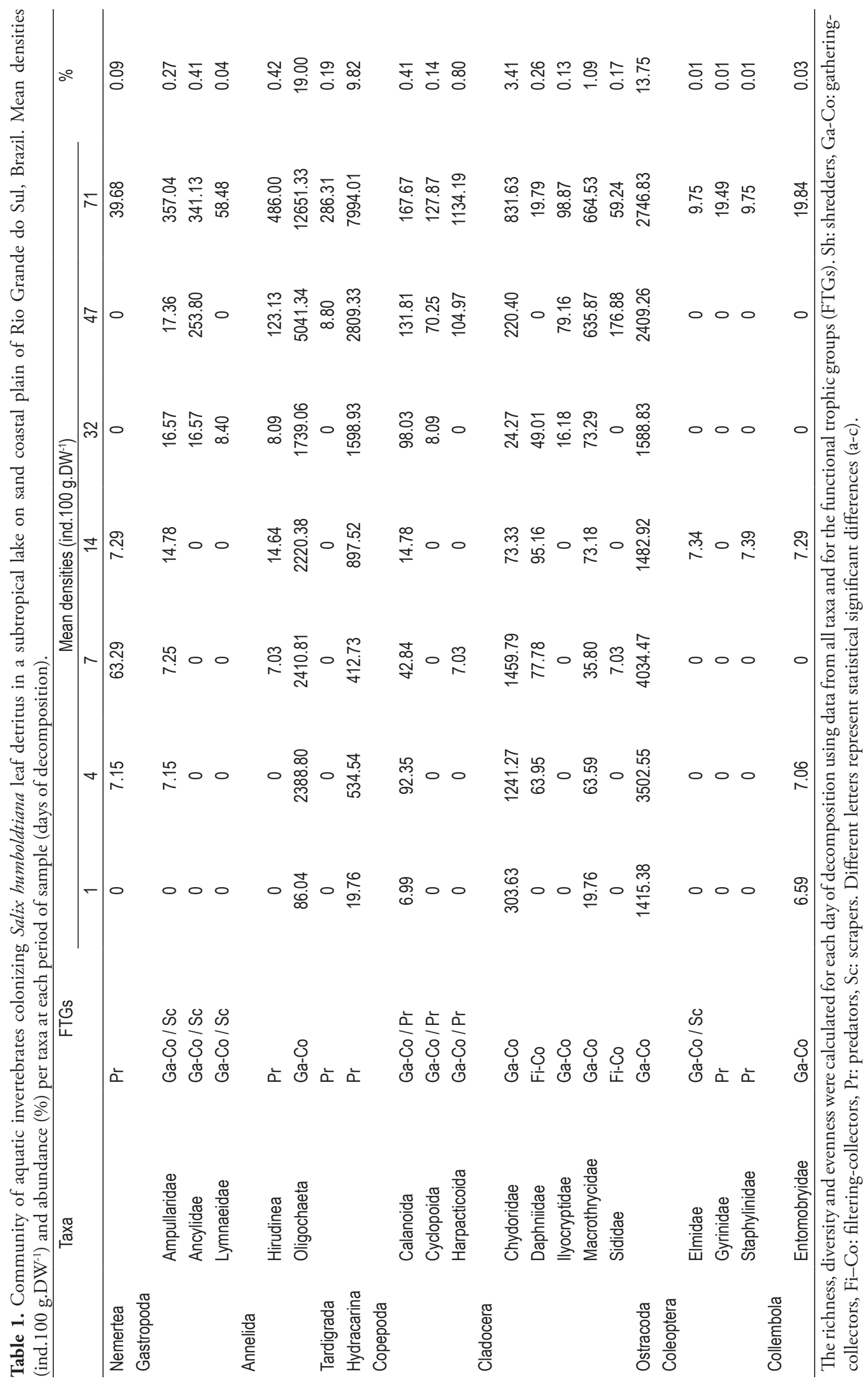




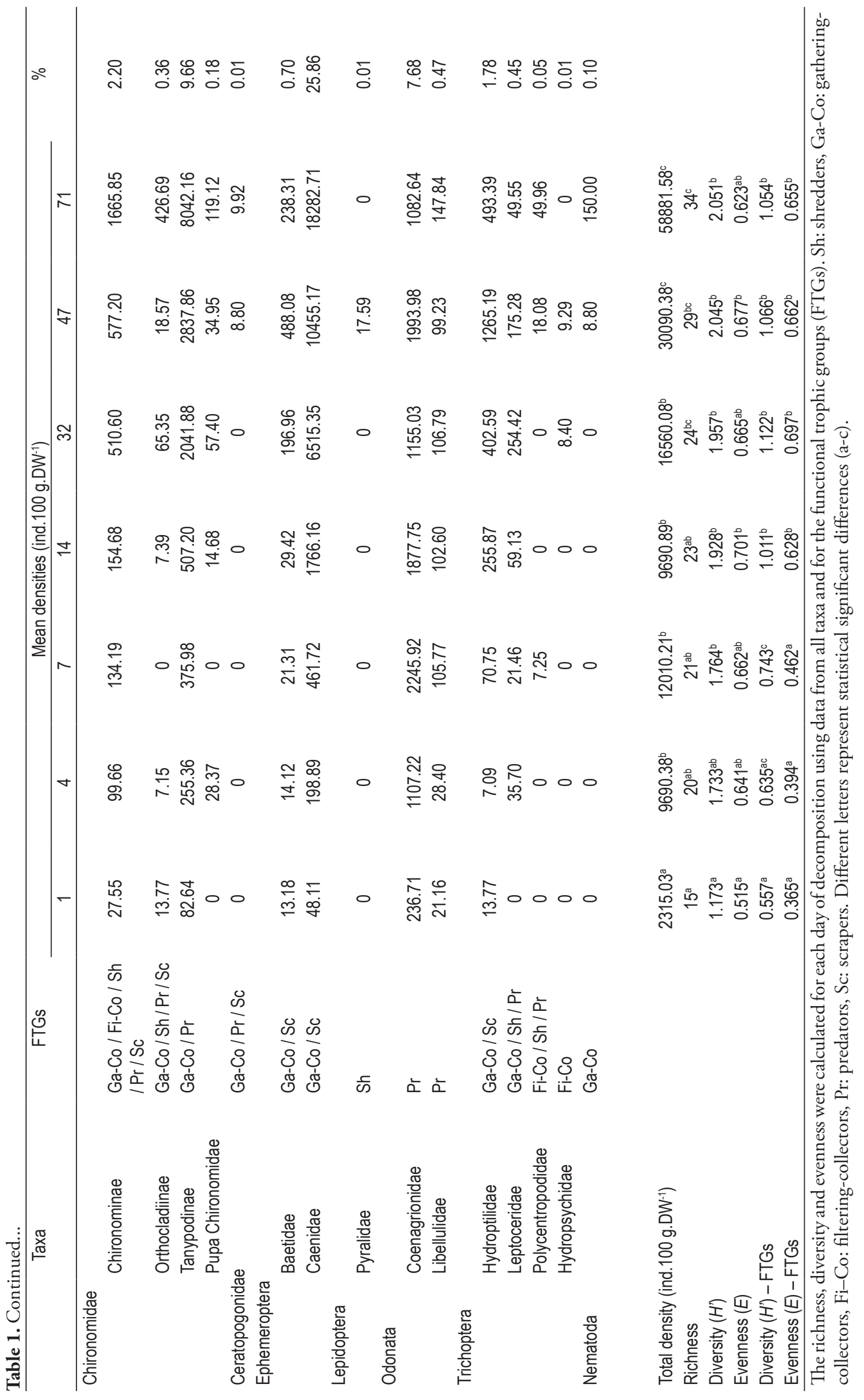


of shredders was observed on day $7(0.3 \%)$ and the highest on day $32(1.23 \%)$. Filtering-collectors presented their lowest abundance $(0.24 \%)$ during the first days of the experiment and their highest $(1.3 \%)$ on day 14 . Significant differences between means were observed for all FTGs (Table 2).

The Shannon diversity index, calculated with respect to FTGs, showed a significant, gradual increase $(F=44.13)$ from the first $(0.557 \pm 0.075)$ to the last day of the experiment $(1.054 \pm 0.014)$ (Table 1). The evenness index also significantly increased $(F=36.04)$ from the beginning to the end of the experiment (day $1=0.365 \pm 0.060$; day $71=0.655 \pm 0.009$ ). These indexes exhibited stabilizing trends by the end of the experiment.

\section{Discussion}

We found that leaf decay coefficients $(k)$ differed between the beginning and the end of the experiment. According to Webster and Benfield (1986), breakdown rates change over time because of the complex nature of plant material. Weight loss is rapid during the first few weeks because of the loss of soluble and labile materials through leaching and microbial metabolism. The remaining material is more resistant to decay, and subsequent weight loss proceeds more slowly. This pattern was observed in the present study.

According to Abelho (2001), various factors can influence the rate of decomposition. In lotic environments, the physical abrasion caused by moving water influences the rate of leaf decay, especially during flood periods (Carvalho and Uieda, 2009a). In lakes, fragmentation by physical abrasion probably has a minimal influence on decomposition. However, waves and water circulation may be important for the processing of detritus (Pabst et al., 2008).

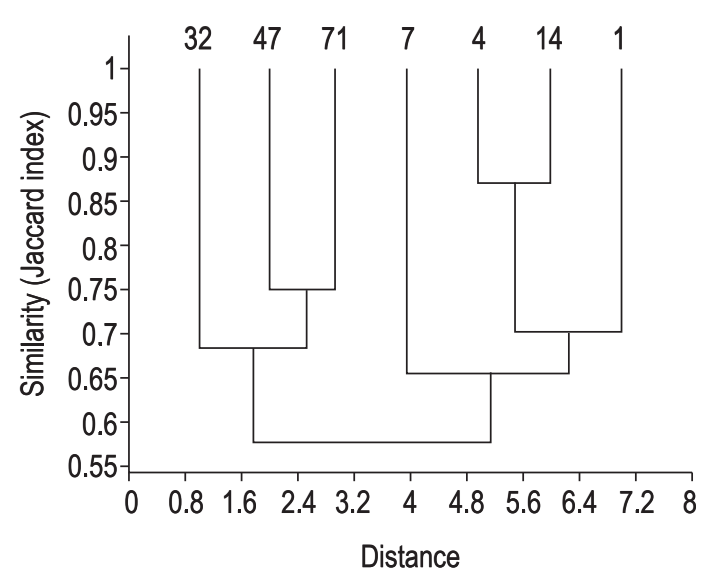

Figure 2. Analysis of community similarity (Jaccard index) constructed with data of presence-absence of invertebrates colonizing Salix humboldtiana leaf detritus, sampled after 1, 4, 7, 14, 32, 47, 71 days of decomposition in a subtropical lake on sand coastal plain of Rio Grande do Sul, Brazil.

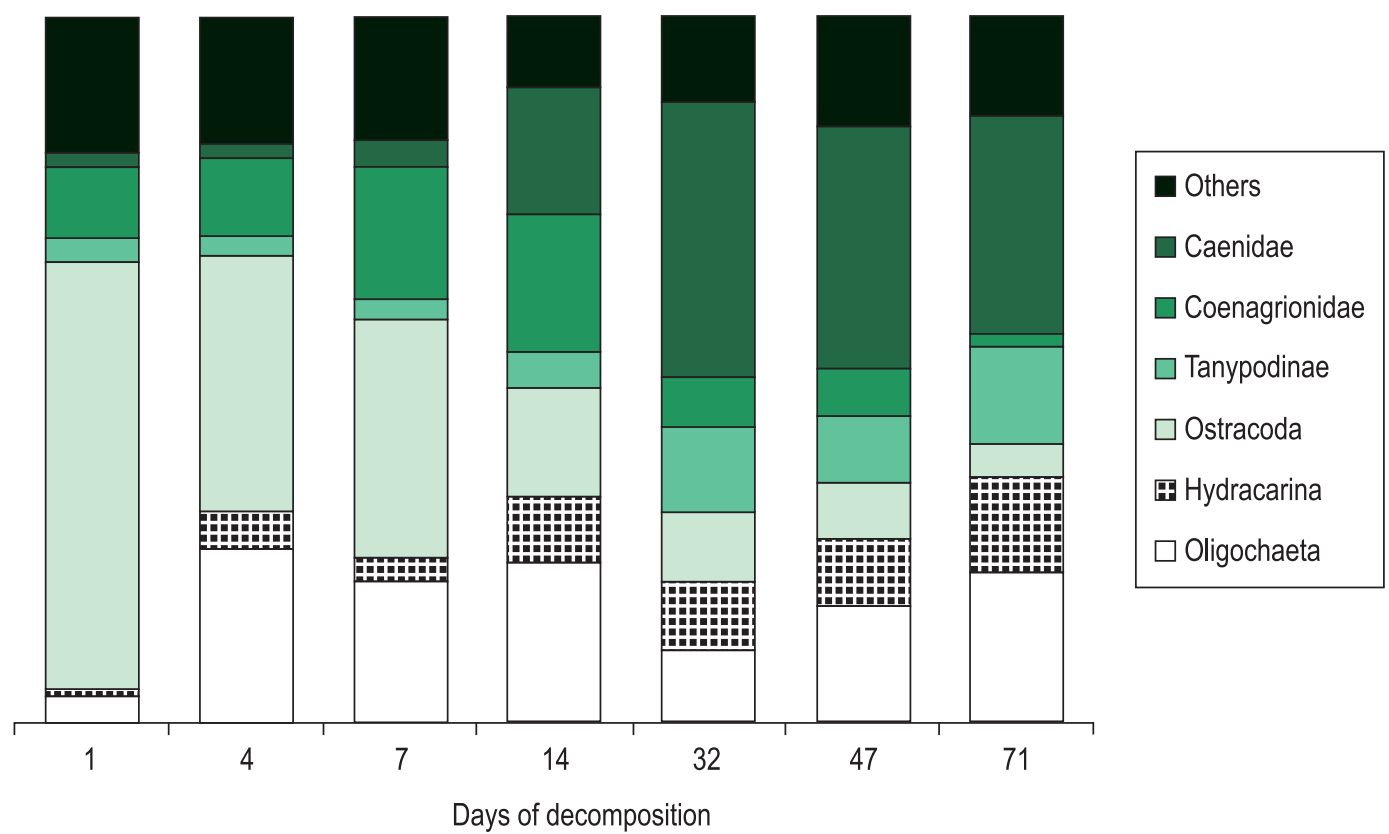

Figure 3. Succession of the most representative taxa (abundance $>7.68 \%$ ) of invertebrates colonizing Salix humboldtiana leaf detritus in a subtropical lake on sand coastal plain of Rio Grande do Sul, Brazil. 
Table 2. Results of ANOVA comparing the means densities of the most representative taxa (abundance > 7.68\%) and functional trophic groups (FTGs) of invertebrates colonizing Salix humboldtiana leaf detritus in a subtropical lake on sand coastal plain of Rio Grande do Sul, Brazil.

\begin{tabular}{|c|c|c|c|c|c|c|c|c|}
\hline \multirow[t]{2}{*}{ Taxa / FTG } & \multicolumn{7}{|c|}{ Days of decomposition } & \multirow[t]{2}{*}{$\mathrm{F}$} \\
\hline & 1 & 4 & 7 & 14 & 32 & 47 & 71 & \\
\hline Oligochaeta & a & $a b$ & $a b$ & $a b$ & $a$ & $b$ & c & 41.51 \\
\hline Hydracarina & a & $\mathrm{b}$ & b & bc & bc & $\mathrm{bc}$ & c & 17.35 \\
\hline Tanypodinae & a & $b$ & $b$ & $b$ & $c$ & $c$ & $d$ & 89.80 \\
\hline Coenagrionidae & a & $a b$ & $\mathrm{~b}$ & $a b$ & $a b$ & $a b$ & $a b$ & 3.34 \\
\hline Caenidae & a & $\mathrm{b}$ & $b$ & $c$ & $d$ & de & $\mathrm{e}$ & 160.07 \\
\hline Gathering-collectors & a & $a b$ & $\mathrm{~b}$ & $a b$ & $\mathrm{~b}$ & $c$ & $d$ & 59.37 \\
\hline Predators & a & $b$ & $\mathrm{bc}$ & bcd & $c d$ & $d$ & e & 55.21 \\
\hline Scrapers & a & $b$ & $\mathrm{~b}$ & c & $d$ & de & e & 96.44 \\
\hline Filtering-collectors & a & $a b$ & $a b$ & b & $b$ & $\mathrm{~b}$ & $\mathrm{~b}$ & 6.15 \\
\hline Shredders & a & $a$ & $a$ & $a b$ & $\mathrm{~b}$ & $b$ & $\mathrm{c}$ & 26.27 \\
\hline
\end{tabular}

Different letters represent statistical significant differences (a-e) $(\mathrm{p}<0.05 ; \mathrm{F}=$ test results).

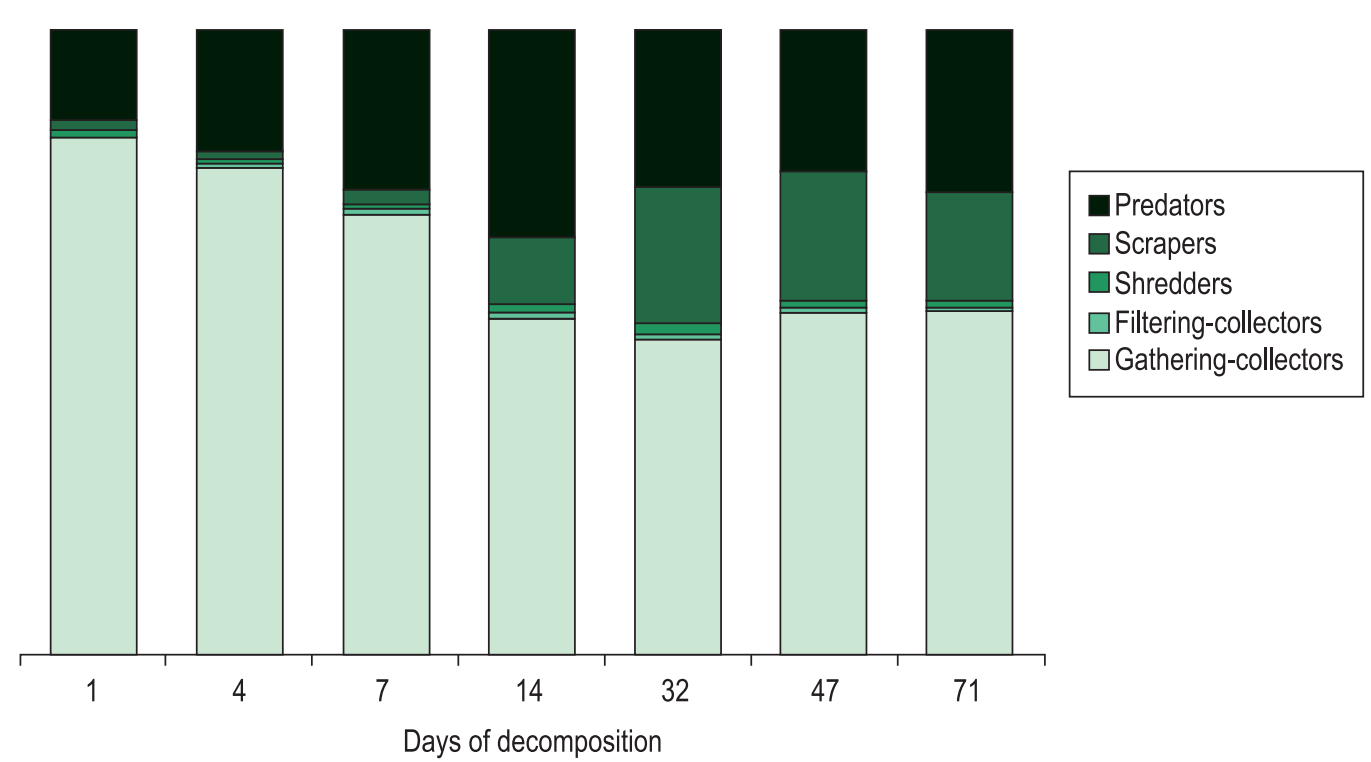

Figure 4. Participation of each functional trophic groups (relative abundance) of invertebrates colonizing Salix humboldtiana leaf detritus in a subtropical lake on sand coastal plain of Rio Grande do Sul, Brazil.

The shallow lakes of the coastal plain of Rio Grande do Sul have a large surface area relative to depth and, due to their location, are strongly influenced by the wind (Furlanetto et al., 2008; Trindade et al. 2009). These characteristics allow such systems to undergo daily circulation of the whole water column, which, in turn, identifies them as holomitic-polimitic lakes (Esteves, 1998). These factors may influence the rate of leaf degradation in shallow lakes of the coastal plain of Rio Grande do Sul.

Considering that $k$ showed a stabilizing trend after day 32, the coefficient estimated for the last day of decomposition can be used to represent the process of mass loss. According to Petersen and
Cummins' (1974) classification, the coefficient found at day 71 in this study $\left(k=0.0100 \mathrm{~d}^{-1}\right)$ represents the threshold between medium and fast degradation velocities. However, all other values obtained in our study are characterized as fast velocities.

The leaf decay coefficient found at the end of the experiment is similar to those found by Leguizamon et al. (1992), Capello et al. (2004) and Poi de Neiff et al. (2006); these authors evaluated the decomposition of $S$. humboldtiana in a new dam $\left(k=0.0101 \mathrm{~d}^{-1} ; 50 \%\right.$ loss $=69$ days; $90 \%$ loss $=228$ days $)$, a river $\left(k=0.0119 \mathrm{~d}^{-1} ; 50 \%\right.$ loss $=58$ days; $95 \%$ loss $=252$ days $)$ and a marsh ( $\mathrm{k}=0.019 \mathrm{~d}^{-1} ; 50 \%$ loss $=36$ days), respectively. All 
studies were performed in the hydrological system of the Paraná River, Argentina.

In our study, the highest rates of weight loss were observed in the initial phase, with a stabilizing trend extending from day 32 to the end of experiment. This behavior was reflected by the composition of the invertebrates colonizing the detritus. As emphasized by the results of similarity analysis, the invertebrates were separated into two groups based on their presence-absence patterns over time. Considering that the mass loss coefficients can probably serve as indirect measures of the potential use of detritus as food resources (Dobson et al., 2003), these two groups may represent the community's overall response to the availability of litter. These results indicate that the availability of detritus may influence the occurrence of different taxa.

The rapid increase in evenness at the beginning of the experiment reflects the decreased dominance of Ostracoda. Though they were present in great abundance at the beginning of the experiment, predation pressure may have contributed to the reduction in their numbers. The subsequent stabilizing trend in evenness resulted from a more balanced distribution of taxa.

We estimated that $95 \%$ of the initial dry weight would be lost after 300 days of decomposition. Combined with the increases in richness, Shannon diversity and total density as well as the achievement of a more balanced distribution of taxa over time, we suggest that $S$. humboldtiana detritus provides a favorable habitat over a sufficient duration to support a high density and diversity of aquatic invertebrates.

In contrast to the findings of the present study, Capello et al. (2004) observed significant decreases in diversity and richness of invertebrates associated with decomposing $S$. humboldtiana in a lotic system. Nevertheless, these authors observed a continual increase in the density of organisms. According to Capello et al. (2004), this increase would be expected in advanced stages of decomposition because of the increase in fine particulate organic matter (FPOM).

We observed a low density of shredders in the present experiment (less than $1 \%$ of the total community). The contribution of this group to the fragmentation of detritus is very significant in temperate zones (Vannote et al., 1980; Graça et al., 2001). In tropical and subtropical regions, however, shredders have low representation in the invertebrate assemblages that colonize detritus (Benstead, 1996; Dudgeon and Wu, 1999; Dobson et al.,
2002; Capello et al., 2004; Gonçalves et al., 2007; Carvalho and Uieda, 2009b). According to Irons et al. (1994), the importance of invertebrate shredders for the decomposition of detritus is lower at low latitudes where the contribution of decomposing microorganisms is greater.

Gathering-collectors were a dominant part of the invertebrate assemblage in the detritus from the first to the last day of our experiment. These organisms are adapted to feed on FPOM (Wallace and Webster, 1996). In lotic environments, they are usually the most abundant group (Lugthart and Wallace, 1992; Callisto et al., 2001, 2004; Carvalho and Uieda, 2009b). According to Richardson (1992) and Grubbs et al. (1995), the dominance of this group is associated with the accumulation of FPOM from its own detritus or from organic particles arising from the seston on the detrital surface. The high abundance of this group observed within the first 24 hours of our experiment indicates that the leaves of $S$. humboldtiana are used primarily as habitat, because FPOM had not yet produced.

The increase in scrapers observed in the present study is probably related to the development of biofilm on the surface of the detritus. Lester et al. (1994) evaluated the development of biofilm on leaves of Salix fragilis L. in a New Zealand river and observed gradual increases in the concentrations of total nitrogen and chlorophyll- $a$ that were related to colonization by microorganisms and periphyton.

Our results suggest that the leaf detritus of S. humboldtiana provides a favorable habitat for a sufficient duration to support a high density and diversity of aquatic invertebrates in Polegar Lake. This community uses the detritus primarily as habitat and secondarily as food (e.g., FPOM). In addition, the detritus provides surface area for the development of biofilms, which are crucial for the recruitment of scrapers. The small percentage of shredders reflects the minor influence of the invertebrate community on the rate of detrital degradation. The main contribution of invertebrates to detrital processing comes from the consumption of FPOM by gathering-collectors.

\section{Acknowledgements}

The authors thanks to the biologists André R. Castillo and Wagner T. Silveira for help in field and laboratory works; to Dr. Luiz Ubiratan Hepp and two anonymous reviewers for improving the manuscript; and CAPES for scholarship to the first author. 


\section{References}

ABELHO, M. 2001. From litterfall to breakdown in streams: a review. The Scientific World, vol. 1, p. 656-680.

ACEÑOLAZA, PG., ZAMBONI, LP., RODRIGUEZ, EE. and GALLARDO, JF. 2010. Litterfall production in forests located at the pre-delta area of the Paraná River (Argentina). Annals of Forest Science, vol. 67, no. 3, p. 1-10. http://dx.doi.org/10.1080/0003379 0.2010 .502426

ALBERTONI, EF., PRELLVITZ, LJ. and PALMASILVA, C. 2007. Macroinvertebrate fauna associated with Pistia stratiotes and Nymphoides indica in subtropical lakes (South Brazil). Brazilian Journal of Biology, vol. 67, no. 3, p. 499-507. http://dx.doi. org/10.1590/S1519-69842007000300015

ASAEDA, T., TRUNG, VK. and MANATUNGE, J. 2000. Modeling the effects of macrophyte growth and decomposition on the nutrient budget in shallow lakes. Aquatic Botany, vol. 68, p. 217-237. http:// dx.doi.org/10.1016/S0304-3770(00)00123-6

BACKES, P. and IRGANG, B. 2002. Árvores do sul: guia de identificaçáo e interesse ecológico. Clube da Árvore, Instituto Souza Cruz. 326 p.

BÄRLOCHER, F. 2005. Leaf mass loss estimated by litter bag technique. In GRAÇA, MAS., BÄRLOCHER, F. and GESSNER, MO., eds. Methods to study litter decomposition. Berlin, New York: Springer. 329 p.

BEDFORD, AP. 2004. A modified litter bag design for use in lentic habitats. Hydrobiologia, vol. 529, p. 187-193.

BEGON, M., HARPER, JL. and TOWNSEND, CR. 1996. Ecology: individuals, populations and communities. 3th ed. Cambridge: Blackwell Science. $1068 \mathrm{p}$.

BENSTEAD, JP. 1996. Macroinvertebrates and the processing of leaf litter in a tropical stream. Biotropica, vol. 28, no. 3, p. 367-375. http://dx.doi. org/10.2307/2389200

BIANCHINI JUNIOR, I. 1999. Aspectos do processo de decomposição nos ecossistemas aquáticos continentais. In POMPÊO, MLM., ed. Perspectivas da limnologia no Brasil. São Luís: Gráfica e Editora União. $191 \mathrm{p}$.

BUCKUP, L. and BOND-BUCKUP, G. 1999. Os crustáceos do Rio Grande do Sul. Porto Alegre: Editora UFRGS. 503 p.

CALLISTO, M., GOULART, M., MEDEIROS, AO., MORENO, P. and ROSA, CA. 2004. Diversity assessment of benthic macroinvertebrates, yeasts and microbiological indicators along a longitudinal gradient in Serra do Cipó, Brazil. Brazilian Journal of Biology, vol. 64, no. 4, p. 743-755. http://dx.doi. org/10.1590/S1519-69842004000500003
CALLISTO, M., MORENO, P. and BARBOSA, FAR. 2001. Habitat diversity and benthic functional trophic groups at Serra do Cipó, Southeast Brazil. Revista Brasileira de Biologia, vol. 61, no. 2, p. 259-266. http://dx.doi.org/10.1590/S003471082001000200008

CAPELLO, S., MARCHESE, M. and EZCURRA DE DRAGO, I. 2004. Descomposición y colonización por invertebrados de hojas de Salix humboldtiana em la llanura aluvial del Río Paraná Medio. Amazoniana, vol. 18, p. 125-143.

CARVALHO, EM. and UIEDA, VS. 2009a. Seasonal leaf mass loss estimated by litter bag technique in two contrasting stretches of a tropical headstream. Acta Limnologica Brasiliensia, vol. 21, no. 2, p. 209-215.

CARVALHO, EM. and UIEDA, VS. 2009b. Diet of invertebrates sampled in leaf-bags incubated in a tropical headwater stream. Zoologia, vol. 26, no. 4, p. 694-704.

CARVALHO, PER. 2003. Espécies arbóreas brasileiras. Brasília: Embrapa Informação Tecnológica; Colombo, Paraná: Embrapa Florestas. 1039 p.

CUMMINS, KW., MERRITT, RW. and ANDRADE, PCN. 2005. The use of invertebrates functional groups to characterize ecosystem attributes in selected streams and rivers in South Brazil. Studies on Neotropical Fauna and Environment, vol. 40, no. 1, p. 69-89. http://dx.doi.org/10.1080/01650520400025720

CUNHA, MB. and BIANCHINI JUNIOR, I. 1998. Mineralização aeróbia de Cabomba piauhyensis e Scirpus cubensis. Acta Limnologica Brasiliensia, vol. 10, no. 2, p. 81-91.

CUNHA, MB. and BIANCHINI JUNIOR, I. 1999. Degradação anaeróbia de Cabomba piauhyensis e Scirpus cubensis: cinéticas de formação de gases. Acta Limnologica Brasiliensia, vol. 11, no. 1, p. 15-26.

DOBSON, M., MAGANA, A., MATHOOKO, JM. and NDEGWA, FK. 2002. Detritivores in Kenyan highland streams: more evidence for the paucity of shredders in the tropics? Freshwater Biology, vol. 47, p. 909-919. http://dx.doi.org/10.1046/j.13652427.2002.00818.x

DOBSON, M., MATHOOKO, JM., NDEGWA, FK. and M'ERIMBA, C. 2003. Leaf litter processing rates in a Kenyan highland stream, the Njoro River. Hydrobiologia, vol. 519, p. 207-210. http://dx.doi. org/10.1023/B:HYDR.0000026592.50734.ea

DUDGEON, D. and WU, KKY. 1999. Leaf litter in a tropical stream: food or substrate for macroinvertebrates? Archiv für Hydrobiologie, vol. 146, p. 65-82.

ELMOOR-LOUREIRO, LMA. 1997. Manual de identificação de cladóceros límnicos do Brasil. Editora Universa. $155 \mathrm{p}$.

ESTEVES, FA. 1998. Fundamentos de Limnologia. $2^{\mathrm{a}} \mathrm{ed}$. Rio de Janeiro: Interciência, FINEP. 575p. 
FURLANETO, LM., TRINDADE, CRT., ALBERTONI, EF. and PALMA-SILVA, C. 2008. Variação limnológica nictemeral e sazonal em um pequeno lago raso subtropical (RS, Brasil). In: Anais do Seminário de estudos limnológicos em clima subtropical, 2008. Rio Grande, Brasil.

GONÇALVES JUNIOR, JF., ESTEVES, FA. and CALLISTO, M. 2000. Sucession and diversity of chironomidae in detritus of Typha domingensis in a coastal lagoon (Parque Nacional da Restinga de Jurubatiba, state of Rio de Janeiro, Brazil). Verh Internat Verein Limnol, vol. 27, p. 2374-2377.

GONÇALVES JUNIOR, JF., ESTEVES, FA. and CALLISTO, M. 2003. Chironomidae colonization on Nymphaea ampla L. detritus during a degradative ecological succession experiment in a brazilian coastal lagoon. Acta Limnologica Brasiliensia, vol. 15, no. 2, p. 21-27.

GONÇALVES JUNIOR, JF., GRAÇA, MAS. and CALLISTO, M. 2007. Litter decomposition in a cerrado savannah stream is retarded by leaf toughness, low dissolved nutrients and a low density of shredders. Freshwater Biology, vol. 52, p. 1440-1451. http:// dx.doi.org/10.1111/j.1365-2427.2007.01769.x

GONÇALVES JUNIOR, JF., SANTOS, AM. and ESTEVES, FA. 2004. The influence of the chemical composition of Typha dominguensis and Nymphaea ampla detritus on invertebrate colonization during decomposition in a brazilian coastal lagoon. Hydrobiologia, vol. 527, p. 125-137. http://dx.doi. org/10.1023/B:HYDR.0000043190.49651.dc

GRAÇA, MAS. 2001. The role of invertebrates on leaf litter breakdown in a stream - a review. International Review of Hydrobiology, vol. 86, p. 383-393.

GRAÇA, MAS., CRESSA, C., GESSNER, M., FEIO, M., CALLIES, K. and BARRIOS, C. 2001. Food quality, feeding preferences, survival and growth of shredders from temperate and tropical streams. Freshwater Biology, vol. 46, p. 947-957. http://dx.doi. org/10.1046/j.1365-2427.2001.00729.x

GRUBBS, SA., JACOBSEN, RE. and CUMMINS, KW. 1995. Colonization by Chironomidae (Insecta, Diptera) on three distinct leaf substrates in an Appalachian mountain stream. Annales de Limnologie, vol. 31, p. 105-118. http://dx.doi.org/10.1051/ $\operatorname{limn} / 1995007$

IRONS, JG., OSWOOD, MW., STOUT, RJ. and PRINGLE, CM. 1994. Latitudinal patterns in leaf litter breakdown: is temperature really important? Freshwater Biology, vol. 32, p. 401-411. http://dx.doi. org/10.1111/j.1365-2427.1994.tb01135.x

JANKE, H. and TRIVINHO-STRIXINO, S. 2007. Colonization of leaf litter by aquatic macroinvertebrates: a study in a low order tropical stream. Acta Limnologica Brasiliensia, vol. 19, p. 109-115.
KIM, JG. and REJMÁNKOVÁ, E. 2004. Decomposition of macrophytes and dynamics of enzyme activities in subalpine marshes in Lake Tahoe basin, U.S.A. Plant and Soil, vol. 266, p. 303-313.

KLEIN, AHF. 1998. Clima Regional. In: SEELIGER, U., ODEBRECHT, C. and CASTELLO, JP., eds. Os Ecossistemas Costeiro e Marinho do Extremo Sul do Brasil. Rio Grande: Editora Ecoscientia. 326 p.

KUFEL, L., KUFEL, I. and KRÓLIKOWSKA, J. 2004. The effect of lake water characteristics on decomposition of aquatic macrophytes. Polish Journal of Ecology, vol. 52, p. 261-273.

LAWTON, J. 1991. Are species useful? Oikos, vol. 62, p. 3-4. http://dx.doi.org/10.2307/3545438

LECERF, A., USSEGLIO-POLATERA, P., CHARCOSSET, JY., LAMBRIGOT, D., BRACHT, B. and CHAUVET, E. 2006. Assessment of functional integrity of eutrophic streams using litter breakdown and benthic macroinvertebrates. Archiv für Hydrobiologie, vol. 165, p. 105-126. http://dx.doi. org/10.1127/0003-9136/2006/0165-0105

LESTER, PJ., MITCHELL, SF. and SCOTT, D. 1994. Willow leaf and periphyton chemical composition, and the feeding preferences of Olinga feredayi (Trichoptera: Conoesucidae). New Zealand Journal of Marine and Freshwater Research, vol. 28, p. 13-18. http://dx.doi.org/10.1080/00288330.1994.9516593

LEGUIZAMON, M., HAMMERLY, J., MAINE, MA., SUNEE, N. and PIZZARO, MJ. 1992. Decomposition and nutrient liberation rates of plant material in the Paraná medio River (Argentina). Hydrobiologia, vol. 230, p. 157-164.

LUGTHART, GJ. and WALLACE, JB. 1992. Effects of disturbance on benthic functional structure and production in mountain streams. Journal of the North American Benthological Society, vol. 11, p. 138-164. http://dx.doi.org/10.2307/1467381

MAGURRAN, AE. 1998. Ecological diversity and its measurement. New Jersey: Princeton University Press. $179 \mathrm{p}$.

MARINHO, CC., PALMA-SILVA, C., ALBERTONI, EF., TRINDADE, CR. and ESTEVES, FA. 2009. Seasonal dynamics of methane in the water column of two subtropical lakes differing in trophic status. Brazilian Journal of Biology, vol. 69, p. 281-287. http://dx.doi.org/10.1590/S151969842009000200007

MERRITT, RW., CUMMINS, KW. and BERG, MB. 2008. An introduction to the aquatic insects of North America. Dubuque: Kendall/Hunt Publishing Co. $1214 \mathrm{p}$.

MUGNAI, R., NESSIMIAN, JL. and BAPTISTA, DF. 2010. Manual de Identificação de Macroinvertebrados Aquáticos do Estado do Rio de Janeiro. Rio de Janeiro: Technical Books. 176 p. 
ODUM, EP. and BARRETT, GW. 2007. Fundamentos de ecologia. 5th ed. São Paulo: Thomson Learning. 612 p.

PABST, S., SCHEIFHACKEN, N., ESSELSCHWERDT, JH. and WANTZEN, K. 2008. Leaf litter degradation in the wave impact zone of a pre-alpine lake. Hydrobiologia, vol. 613, p. 117-131. http://dx.doi. org/10.1007/s10750-008-9477-y

PASCOAL, C., PINHO, M., CÁSSIO, F. and GOMES, P. 2003. Assessing structural and functional ecosystem condition using leaf breakdown: studies on a polluted river. Freshwater Biology, vol. 48, p. 2033-2044. http://dx.doi.org/10.1046/j.13652427.2003.01130.x

PETERSEN, RC. and CUMMINS, KW. 1974. Leaf processing in a woodland stream. Freshwater Biology, vol. 4, p. 343-368. http://dx.doi. org/10.1111/j.1365-2427.1974.tb00103.x

PIECZYNSKA, E. 1986. Sources and fate of detritus in the shore zone of lakes. Aquatic Botany, vol. 25, p. 153-166. http://dx.doi.org/10.1016/03043770(86)90051-3

POI DE NEIFF, A., NEIFF, JJ. and CASCO, SL. 2006. Leaf litter decomposition in three wetland types of the Paraná River flood plain. Wetlands, vol. 26, p. 558-566. http://dx.doi.org/10.1672/02775212(2006)26[558:LLDITW]2.0.CO;2

POPE, RJ., GORDON, AM. and KAUSHIK, NK. 1999. Leaf litter colonization by macroinvertebrates in the littoral zone of a small oligotrophic lake. Hydrobiologia, vol. 392, p. 99-112. http://dx.doi. org/10.1023/A:1003537232319

RICHARDSON, JS. 1992. Food, microhabitat, or Both? Macroinvertebrate use of leaf accumulations in a montane stream. Freshwater Biology, vol. 27, p. 169-176. http://dx.doi. org/10.1111/j.1365-2427.1992.tb00531.x

SAMPAIO, A., RODRÍGUEZ-GONZÁLEZ, P., VARANDAS, S., CORTES, RM. and FERREIRA, MT. 2008. Leaf litter decomposition in western iberian forested wetlands: lentic versus lotic response. Limnetica, vol. 27, p. 93-106.

SHILLA, D., ASAEDA, T., FUJINO, T. and SANDERSON, B. 2006. Decomposition of dominant submerged macrophytes: implications for nutrient release in Myall Lake, NSW, Australia. Wetlands Ecology and Management, vol. 14, p. 427-433. http://dx.doi.org/10.1007/s11273006-6294-9

THORP, JH. and COVICH, AP. 1991. Ecology and classification of North American freshwater invertebrates. New York: Academic Press, Inc. 911 p.

TRINDADE, CRT., FURLANETTO, LM., ALBERTONI, EF. and PALMA-SILVA, C. 2008. Nutrientes no tecido de macrófitas aquáticas de diferentes corpos d'água rasos subtropicais (Rio Grande - RS - Brasil). In Anais do Seminário de estudos limnológicos em clima subtropical, 2008. Rio Grande, Brasil.

TRINDADE, CRT., FURLANETTO, LM. and PALMA-SILVA, C. 2009. Nycthemeral cycles and seasonal variation of limnological factors of a subtropical shallow lake (Rio Grande, RS, Brazil). Acta Limnologica Brasiliensia, vol. 21, p. 35-44.

TRINDADE, CRT., PEREIRA, SA., ALBERTONI, EF. and PALMA-SILVA, C. 2010. Caracterização e importância das macrófitas aquáticas com ênfase nos ambientes límnicos do Campus Carreiros - FURG, Rio Grande, RS. Cadernos de Ecologia Aquática, vol. 5, p. 1-22.

VANNOTE, RL., MINSHALL, GW., CUMMINS, KW., SEDELL, JR. and CUSHING, CE. 1980. The River Continuum Concept. Canadian Journal of Fisheries and Aquatic Sciences, vol. 37, p. 817-822.

VIEIRA, EF. and RANGEL, SS. 1988. Planície costeira do Rio Grande do Sul: Geografia física, vegetação e dinâmica sócio-demográfica. Porto Alegre: Editora Sagra. 256 p.

WALLACE, JB. and WEBSTER, JR. 1996. The role of macroinvertebrates in stream ecosystem function. Annual Review of Entomology, vol. 41, p. 115-139. http://dx.doi.org/10.1146/annurev. en.41.010196.000555

WEBSTER, JR. and BENFIELD, EF. 1986. Vascular plant breakdown in freshwater ecosystems. Annual Review of Ecology, Evolution and Systematics, vol. 17, p. 567-94. http://dx.doi.org/10.1146/annurev. es.17.110186.003031 